\title{
Pengaruh Kepemimpinan Stratejik Terhadap Strategi Bersaing UKM Café dan Restoran
}

\author{
Intan Widya Anugrah ${ }^{1 *}$ dan Tintin Suhaeni ${ }^{2}$ \\ ${ }^{1}$ Jurusan Administrasi Niaga, Politeknik Negeri Bandung, Indonesia \\ ${ }^{2}$ Jurusan Administrasi Niaga, Politeknik Negeri Bandung, Indonesia
}

\begin{abstract}
:
Along with high competition, the ability to survive in the business world strategic leadership is needed to face the competition. Strategic leadership that has dimensions of vision, business model articulation, information delivery well, clever in handling power, and emotional intelligence is one of the factors needed in the company in choosing the appropriate strategy competitiveness. While the competitive strategy itself has a dimension of leadership that low cost, differentiation and focus. This study aims to measure great strategic leadership, competitive strategy and how much strategic leadership relationship and competitive strategy in SMEs cafe and restaurant. The population of this study is 557 SMEs cafe and restaurant it Kecamatan Bandung Wetan, with a sample of 50 SMEs. The methodology used is descriptive method associative. In this study using simple regression method obtained regression equation $Y=16043+0,306 X$, it means to have a positive relationship of 0.401 . The result of research stated that strategic leadership influence 16,08\% toward competitive strategy at SMEs cafe and restaurant.
\end{abstract}

Keywords: leadership strategic, competitive strategy, competitiveness

\begin{abstract}
Abstrak:
Seiring dengan persaingan yang tinggi, kemampuan bertahan di dunia bisnis. Kepemimpinan strategis dibutuhkan untuk menghadapi persaingan. Kepemimpinan strategis yang memiliki dimensi visi, artikulasi model bisnis, penyampaian informasi dengan baik, pandai dalam menangani daya, dan kecerdasan emosional merupakan salah satu faktor yang dibutuhkan dalam perusahaan dalam memilih strategi bersaing yang tepat. Sedangkan strategi bersaing itu sendiri memiliki dimensi kepemimpinan yang berbiaya rendah, diferensiasi dan fokus. Penelitian ini bertujuan untuk mengukur strategi kepemimpinan yang hebat, strategi bersaing dan seberapa besar hubungan kepemimpinan strategis dan strategi bersaing di UKM kafe dan restoran. Populasi penelitian ini adalah 557 UKM kafe dan restoran Kecamatan Bandung Wetan, dengan sampel 50 UKM. Metodologi yang digunakan adalah metode deskriptif asosiatif. Dalam penelitian ini menggunakan metode regresi sederhana diperoleh persamaan regresi $\mathrm{Y}=16043+0,306 \mathrm{X}$, artinya memiliki hubungan positif sebesar 0,401 . Hasil penelitian menyatakan bahwa kepemimpinan strategis berpengaruh $16,08 \%$ terhadap strategi bersaing di UKM kafe dan restoran.
\end{abstract}

Kata Kunci: strategi kepemimpinan, strategi kompetitif, daya saing

*Email korespondensi:

Intan Widya Anugrah

intanwanugrah@gmail.com

\section{PENDAHULUAN}

Dunia bisnis yang memicu lingkungan kompetitif, telah memacu setiap organisasi untuk terus 
meningkatkan dan memaksimalkan usaha serta potensi usaha mereka. Kota Bandung sendiri jumlah UMKM dari tahun ke tahun semakin meningkat.

Dalam menghadapi persaingan yang ketat seperti saat ini, perusahaan kecil maupun menengah harus memperhatikan strategi yang dimilikinya agar mampu menghadapi persaingan itu. Salah satu strategi yang harus dilakukan oleh perusahaan untuk dapat bertahan di dalam persaingan yang ketat adalah strategi bersaing. Strategi bersaing dapat digambarkan sebagai sebuah proses bagaimana perusahaan membangun dan mengembangkan berbagai sumber daya stratejiknya yang memiliki potensi untuk menghasilkan keunggulan bersaing.

Tabel 1 Jumlah UKM di Kota Bandung

\begin{tabular}{|c|l|c|c|c|}
\hline \multirow{2}{*}{ No } & \multirow{2}{*}{ Uraian } & $\mathbf{2 0 1 4}$ & $\mathbf{2 0 1 5}$ & $\mathbf{2 0 1 6}$ \\
\cline { 3 - 5 } 1 & Mikro & 4.301 & 4.578 & 4689 \\
\hline 2 & Kecil & 372 & 392 & 395 \\
\hline 3 & Menengah & 276 & 281 & 281 \\
\hline & Jumlah & 4.948 & 5.251 & 5365 \\
\hline
\end{tabular}

Berdasarkan Tabel 1 persaingan yang semakin tinggi, kepemimimpinan merupakan hal yang dibutuhkan, salah satunya adalah kepemimpinan stratejik. Kepemimpinan strategis lebih jauh berarti kemampuan yang dimiliki pemimpin untuk mengelola, mengkoordinasikan, memengaruhi serta memotivasi dan meningkatkan kinerja orang-orang yang dipimpinnya untuk mencapai tujuan organisasi khususnya di UKM Cafe dan restoran.

Berdasarkan observasi awal, kenyataanya tidak banyak perusahaan yang bertahan di industri makanan khususnya cafe dan restoran dikarenakan tingginya persaingan tetapi pemimpin yang tidak tanggap dengan persaingan yang tinggi tersebut, hal ini ditandai dengan belum efektifnya kepemimpian stratejik yang mengakibatkan tidak bertahan di persaingan. UKM kuliner di kecamatan Bandung Wetan Kota
Bandung dan menunjukan bahwa perusahaan tidak bertahan atau mengalami penurunan omzet karena tidak mampu menghadapi persaingan.

Tabel 2 Data Omzet UKM di Kecamatan Bandung Wetan

\begin{tabular}{|c|l|c|c|c|}
\hline \multirow{2}{*}{ No } & \multirow{2}{*}{ Perusahaan } & \multicolumn{3}{|c|}{ Omzet } \\
\cline { 3 - 5 } & & $\mathbf{2 0 1 4}$ & $\mathbf{2 0 1 5}$ & $\mathbf{2 0 1 6}$ \\
\hline 1 & Mie Merapi & $50 \mathrm{M}$ & $48 \mathrm{M}$ & $43.8 \mathrm{M}$ \\
\hline 2 & Boober Cafe & $12 \mathrm{M}$ & $11.5 \mathrm{M}$ & $10 \mathrm{M}$ \\
\hline 3 & Pepo Appetite & $7,5 \mathrm{M}$ & $8.3 \mathrm{M}$ & $8 \mathrm{M}$ \\
\hline
\end{tabular}

Dari pernyataan diatas, bahwa dengan tidak dilibatkannya karyawan dalam memberikan ide baru pada menu dan pemasaran, ketidaktahuan karyawan terhadap visi serta tujuan perusahaan, dan semua masalah dan keputusan yang diambil oleh pemimpin, maka hal tersebut mengindikasikan bahwa kepemimpinan stratejik di perusahaan tidak berjalan, sehingga hal tersebut berdampak pada perusahaan sulit bersaing di industri, hal tersebut berdampak pada omzet perusahaan yang dapat dilihat pada Tabel Sedangkan jika menurut Agyapong (2013) menyatakan bahwa dalam berkembang di lingkungan bisnis yang kompetitif ini memerlukan keunggulan kompetitif yang berkelanjutan melalui bisnis yang koheren dan strategi bersaing, serta UKM memperoleh keunggulan kompetitif melalui kemampuan mereka untuk mengembangkan dan memperoleh sumber daya organisasi dan kapabilitas, mengambil posisi pasar strategis, dan menerapkan strategi kompetitif untuk mengenali peluang dan ancaman di lingkungan eksternal.

\section{KAJIAN LITERATUR} Kepemimpinan Stratejik

"Untuk bisa bersaing di dalam pasar persaingan yang global, organisasi membutuhkan kepemimpinan yang kuat dan efektif" (Dess et al., 2008). Kepemimpinan adalah suatu proses dimana individu mempengaruhi kelompok untuk mencapai tujuan umum Northouse 
dalam Thoyib (2012). Pengertian ini dipertajam bahwa kepemimpinan itu adalah kemampuan untuk menanamkan keyakinan dan memperoleh dukungan dari anggota organisasi untuk mencapai tujuan organisasi Dubrin, A. J. Dalam Thoyib (2012). Sedangkan menurut Dess et al. (2008) kepemimpin adalah agen perubahan yang sukses dalam meyakinkan bagaimana mereka mengimplementasikan strategi untuk mencapai visi dan misi mereka. Sehingga dapat disimpulkan bahwa keemimpinan adalah kemampuan seseorang untuk mempengaruhi orang lain atau anggota dalam mencapai tujuan organisasi.

$$
\text { Selanjutnya Yulk (2010) }
$$

kemampuan pemimpin melakukan tindakan strategisnya bergantung pada faktor historis organisasi (budaya organisasi) yang dipengaruhi oleh perubahan lingkungan eksternal (hadirnya kompetitor baru, perkembangan teknologi, menurunnya permintaan jasa/produk, iklim politik/peraturan yang berbeda), penguatan strategi dan peningkatan konsistensi antara strategi, struktur organisasi, budaya dan sumber daya manusia. Bianco dan Schermerhorn dalam Winerungan dan Thoyib (2012), berpendapat bahwa ciri atau karakteristik kepemimpinan strategis yakni: terlibat dalam perubahan, lebih proaktif dalam mengkomunikasikan perubahan, tidak bersedia mengubah kepemimpinan menjadi konsultan eksternal serta tidak sekedar memiliki visi perubahan namun disertai kapasitas berkelanjutan untuk implementasi perubahan, selalu mendorong terciptanya perubahan perilaku secara positif, mandiri dan memungkinkan orang lain melakukan hal yang sama serta berani mengambil resiko.

Rothaerment (2015) mengatakan bahwa "Strategy Leadership is the behaviour and styles of executives that influence others to achieve the organization" . Sedangkan menurut Ireland and Hitt (2008) mendefinisikan kepemimpinan strategis sebagai "the ability to anticipate, envision, maintain flexibility and empower others to create strategic change as necessary. Sedangkan, Sachin and Bansidhar (2013) mendefinisikan kepemimpinan strategis sebagai "the ability to influence others to voluntarily make day-to-day decisions that enhance the long-term viability of the organisation, while at the same time maintaining its short-term financial stability".

Dari beberapa pengertian diatas dapat ditarik kesimpulan bahwa kemampuan pemimpinan yang dapat melihat kedepan untuk mempengaruhi orang lain atau anggotanya untuk bisa mencapai tujuan serta terlibat di dalam perubahan sehingga perusahaan atau organisai dapat bertahan di dalam persaingan.

\section{Strategi Bersaing}

Menurut Chandler (1962) strategi merupakan penetapan sasaran dan tujuan jangka panjang sebuah perusahaan dan arah tindakan serta alokasi sumber daya yang diperlukan untuk mencapai sasaran dan tujuan itu. Sedangkan dalam manajeman strategi yang baru, Mintzberg dalam Porter (2015) mengemukakan 5P yang sama artinya dengan strategi, yaitu Strategi adalah Perencanaan (Plan) Konsep strategi tidak lepas dari aspek perencanaan, arahan atau acuan gerak langkah perusahaan untuk mencapai suatu tujuan di masa depan. Akan tetapi, tidak selamanya strategi adalah perencanaan ke masa depan yang belum dilaksanakan. Strategi juga menyangkut segala sesuatu yang telah dilakukan sebelumnya. Strategi adalah Pola (Patern)

Menurut Mintzberg (2014) "strategy is patern", yang selanjutnya disebut sebagai intended strategy, karena belum terlaksana dan berorientasi ke masa depan. Atau disebut juga sebagai realized strategy karena telah dilakukan oleh perusahaan. Strategi adalah Posisi 
(Position) yaitu memposisikan produk tertentu ke pasar tertentuyang dituju. Strategi sebagai posisi cenderung melihat ke bawah, yaitu ke suatu titik bidik di mana produk tertentu bertemu dengan pelanggan, dan melihat ke luar yaitu meninjau berbagai aspek lingkungan eksternal. Strategi adalah Perspektif (Perspektif) jika dalam arti Pola dan Posisi cenderung melihat ke bawah dan ke luar, maka sebaliknya dalam Perspektif cenderung lebih melihat ke dalam yaitu ke dalam organisasi, dan ke atas yaitu melihat grand vision dari perusahaan. Strategi adalah Permainan (Play) artinya strategi adalah suatu manuver tertentu untuk memperdaya lawan atau pesaing. Suatu merek misalnya meluncurkan merek kedua agar posisinya tetap kukuh dan tidak tersentuh, karena merek-merek pesaing akan sibuk berperang melawan merek kedua tadi.

Cara perusahaan untuk mendapatkan keunggulan kompetitif yang berkelanjutan merupakan inti dari strategi bersaing. Pilihan strategi bersaing didasarkan pada keunggulan kompetitif yang dapat dikembangkan oleh organisasi. Bagaimana cara organisasi akan bersaing dalam suatu industri adalah pilihan strategi bersaing. Menurut Porter dalam Wheelen and Hunger (2012), strategi bersaing dapat dilakukan dengan kepemimpinan biaya, diferensiasi, dan focus atau biasa disebut dengan strategi bersaing generik.

Porter dalam Wheelen and Hunger (2012) mengungkapkan beberapa strategi yang dapat digunakan perusahaan untuk bersaing. Beberapa aspek inti dari teori Porter tersebut adalah:

1. Persaingan merupakan inti keberhasilan dan kegagalan. Hal ini berarti bahwa keberhasilan atau kegagalan bergantung pada keberanian perusahaan untuk dapat bersaing. Strategi bersaing dimaksudkan untuk mempertahankan tingakat keuntungan dan pasisi yang langeng ketika menghadapi
persaingan.

2. Keunggulan bersaing berkembang dari nilai yang mampu diciptakan oleh perusaan bagi langganan atau pembeli. Keunggulan bersaing menggambarkan cara perusahaan memilih dan dan mengimplementasikan strategi generik untuk mencapai dan mempertahankan keunggulan bersaing.

3. Ada dua jenis dasar keunggulan bersaing, yaitu biaya rendah dan diferensiasi. semua keunggulan bersaing ini berasal dari struktur industri. perusahaan yang berhasil dengan strategi biaya rendah memiliki kemampuan dalam mendisain produk dan pasar yang lebih efisien dibandingkan pesaing. Sedangkan diferensiasi adalah kemapuan untuk menghasilkan barang dan jasa unit serta memiliki nilai lebih bagi pembeli dan bentuk kualitas produk, sifat-sifat khusus, dan pelayanan lainnya.

Menurut Porter dalam R. Terry (2006) perusahaan kadang bisa dengan sukses menggunakan lebih dari satu strategi bersaing generik. Implementasi pada strategi bersaing ini membutuhkan komitemn dan dukungan dari organisasi untuk bisa mencapai tujuannya yaitu mendapatkan keunggulan bersaing sehingga pesaing sulit untuk meniru produk yang kita tawarkan kepada konsumen.

\section{METODE PENELITIAN Metode Penarikan Sampel}

Dalam penelitian ini, penulis menggunakan jenis metode non probability sampling. Teknik pengambilan sampel yang digunakan adalah purposive sampling.

Menurut Cohen, et.al, (2007) semakin besar sampel dari besarnya populasi yang ada adalah semakin baik, akan tetapi ada jumlah batas minimal yang harus diambil oleh peneliti yaitu 
sebanyak 30 sampel untuk organisasi. Populasi dalam penelitian ini adalah Usaha Kecil Menengah Cafe dan Restoran di Kecamatan Bandung Wetan Kota Bandung sebanyak 557, berdasarkan teori diatas penulis mengambil 35 perusahaan, yang rata-rata jumlah pegawai minimal 815 pegawai, dan sudah berjalan selama minimal 3 tahun sebagai representatif perusahaan yang sudah stabil dalam menjalani bisnisnya, dan serta sudah memiliki manajemen di dalam perusahaannya, sesuai dengan syarat UKM berdasarkan Lembaga Pengembangan Perbankan Indonesia.

Tabel 3 Data Demografi

\begin{tabular}{|c|c|c|}
\hline \multirow{2}{*}{$\begin{array}{c}\text { Jenis } \\
\text { Kelamin }\end{array}$} & Pria & 65 \\
\hline & Wanita & 45 \\
\hline \multirow{3}{*}{$\begin{array}{c}\text { Usia } \\
\text { Responden }\end{array}$} & 20-30 tahun & 17 \\
\hline & $31-40$ tahun & 66 \\
\hline & 41-50 tahun & 33 \\
\hline \multirow{3}{*}{$\begin{array}{c}\text { Pendidikan } \\
\text { Terakhir }\end{array}$} & $\mathrm{S} 1$ & 49 \\
\hline & $\mathrm{S} 2$ & 50 \\
\hline & SMA/SMK & 11 \\
\hline \multirow{3}{*}{$\begin{array}{c}\text { Bentuk } \\
\text { Usaha }\end{array}$} & $\mathrm{CV}$ & 28 \\
\hline & PT (Perseroan Terbatas) & 22 \\
\hline & Perseorangan & 64 \\
\hline \multirow{5}{*}{$\begin{array}{l}\text { Jumlah } \\
\text { Pegawai }\end{array}$} & Kurang dari 10 orang & 2 \\
\hline & 11-20 orang & 30 \\
\hline & $21-30$ orang & 35 \\
\hline & $31-40$ orang & 26 \\
\hline & Lebih dari 50 orang & 17 \\
\hline \multirow{3}{*}{ Lama Usaha } & $2-5$ tahun & 70 \\
\hline & 6-10 tahun & 30 \\
\hline & Lebih dari 10 tahun & 10 \\
\hline \multirow{6}{*}{$\begin{array}{c}\text { Omzet } \\
\text { Pebulan }\end{array}$} & Rahasia & 7 \\
\hline & $<10$ juta & 3 \\
\hline & $10-20$ juta & 37 \\
\hline & 21-30 juta & 11 \\
\hline & $31-40$ juta & 13 \\
\hline & Lebih dari 50 juta & 39 \\
\hline
\end{tabular}

HASIL DAN PEMBAHASAN

\section{Analisis Deskriptif Variabel Kepemimpinan Stratejik}

Berdasarkan Tabel 4 dapat diketahui bahwa nilai rata-rata (mean) kepemimpinan stratejik yang dimiliki oleh responden adalah sebesar 2,86 dengan nilai minimum dua (rendah) dan nilai tertinggi lima (sangat tinggi). Nilai mean tersebut berada pada interval pada interval kedua. Hal ini mengartikan bahwa para pengusaha kecil dan menengah pada cafe dan restoran di Kota Bandung Kecamatan Bandung Wetan memiliki tingkat kepemimpinan yang cukup baik/tinggi.

Tabel 4 Statistik Deskriptif Variabel Kepemimimpian Stratejik

\begin{tabular}{|l|r|r|r|r|}
\hline & Min & Max & Mean & $\begin{array}{l}\text { Std. } \\
\text { Dev }\end{array}$ \\
\hline Visi & 2 & 4 & 2,75 &, 638 \\
\hline $\begin{array}{l}\text { Artikulasi Model } \\
\text { Bisnis }\end{array}$ & 2 & 5 & 3,59 &, 793 \\
\hline $\begin{array}{l}\text { Menyampaikan } \\
\text { informasi dengan } \\
\text { baik }\end{array}$ & 2 & 5 & 3,28 &, 660 \\
\hline $\begin{array}{l}\text { Cerdik } \\
\text { menangani } \\
\text { kekuasaan }\end{array}$ & 2 & 4 & 3,02 &, 686 \\
\hline $\begin{array}{l}\text { Kecerdasan } \\
\text { Emosional }\end{array}$ & 2 & 4 & 3,28 &, 509 \\
\hline $\begin{array}{l}\text { Kepemimpinan } \\
\text { Stratejik }\end{array}$ & $\mathbf{3}$ & $\mathbf{4}$ & $\mathbf{3 , 2 5}$ & $\mathbf{, 5 0 8}$ \\
\hline $\begin{array}{l}\text { Valid N } \\
\text { (listwise) }\end{array}$ & & & & \\
\hline
\end{tabular}

Variabel kepemimpinan stratejik diukur oleh lima dimensi, diantaranya adalah visi, artikulasi model bisnis, bijak dalam mengambil kekuasaan, kecerdasan emosional. Jika dilihat dari Tabel 4 bahwa dimensi dari variabel kepemimpinan stratejik yang memiliki nilai rata-rata yang tinggi/baik, sedangkan dimensi yang lainnya termasuk kategori cukup baik/tinggi.

Kepemimpinan stratejik yang cukup baik megindikasikan bahwa pemimpin belum optimal dalam penyampaikan visi perusahaan, pemaham terhadap model artikulasi model bisnis, penyampaian informasi dengan baik, cerdik dalam penanganan kekuasaan, dan kepemilikan kecerdasan emosional. Sesuai dengan penjelasan menurut Hill and Jones (2013) bahwa pemimpin harus mampu menyampaikan visi perusahaan serta konsisten dalam menjalankannya, pemimpin paham menyelesaikan masalah di perusahaan, dan tanggap menghadapi masalah perusahaan termasuk karyawan, pemimpin mampu dalam menyampaikan 
arahan serta informasi kepada karyawan, pemimpin mampu dan bijak dalam memberikan tanggung jawab kepada karyawan, emotional intellegent artinya pemimpinn mampu mengontrol emosi diri. Hal ini mungkin dikarenakan pemimpin yang masih tidak percaya kepada karyawan untuk memberikan kontribusi pada strategi yang akan diambil, selain itu pemimpin masih ada yang kurang konsisten terhadap visi yang telah ditanam di perusahaan sehingga banyak karyawan dari beberapa UKM yang tidak mengetahui visi perusahaan, namun jika dilihat dari sisi yang lain pemimpin di UKM cafe dan restoran memahami terhadap masalah di perusahaan, mampu menyampaikan arahan dan informasi dengan mudah dipahami karyawan, dan pengendalian emosi dan empati yang baik dari pemimpin di UKM tersebut.

Dimensi dengan nilai mean (ratarata) tertinggi ditunjukkan oleh dimensi artikulasi model bisnis sedangkan nilai mean (rata-rata) terendah ditunjukkan oleh dimensi bijak dalam menangani kekuasaan. Namun jika dilihat dari koefisien variansi yang lebih dari $20 \%$ maka jawaban yang beragam, atau artinya rata-rata jawaban ini tidak mewakili keseluruhan jawaban responden, hal tersebut terjadi karena banyaknya perusahaan yang kepemilikannya dimiliki oleh persorangan yang masih banyak belum mempercayai orang lain untuk mengambil keputusan, sedangkan yang berbentuk CV ataupun PT (Perseroanan Terbatas) banyak sudah melakukan pendelegasian tugas dengan baik.

Hertawan (2015) menyatakan
bahwa lingkungan bisnis dan kepemimpinan stratejik memberikan pengaruh yang lebih besar terhadap kinerja bisnis melalui strategi bersaing dibandingkan dengan pengaruh langsung lingkungan bisnis dan kepemimpian stratejik terhadap kinerja bisnis. Sehingga kepemimpinan stratejik yang termasuk kategori cukup baik/tinggi merupakan salah satu faktor yang mempengaruhi stratgi bersaing di UKM cafe dan restoran. Untuk meningkatkan kepemimpinan stratejik yang belum maksimal tersebut menurut Dess et al. (2008) harus diawali oleh diri pemimpin tersebut untuk percaya kepada orang lain.

\section{Analisis Deskriptif Variabel Strategi Bersaing}

Berdasarkan Tabel 5 dapat diketahui bahwa nilai rata-rata (mean) strategi bersaing yang dimiliki oleh responden adalah sebesar 3,39. Nilai mean tersebut berada pada interval pada interval cukup baik, hal ini mengindikasikan bahwa UKM cafe dan restoran di Kecamatan Bandung Wetan Kota Bandung ini belum maksimal dalam menjalankan strategi kepemimpinan biaya, differensiasi produk dan fokus untuk memenangkan pasar.

Hasil rata-rata setiap dimensi tersebut pun berada pada kategori baik. Dimensi dengan nilai mean (rata-rata) tertinggi berada pada kategori baik. Dimensi dengan nilai mean tertinggi ditunjukkan oleh dimensi fokus, sedangkan yang dimensi dengan nilai mean (rata-rata) terendah adalah diferensiasi produk dengan kategori cukup baik/tinggi. Hal ini mengindikasikan bahwa sebagian besar UKM cafe dan restoran di Kota Bandung Kecamatan Bandung Wetan menggunakan strategi fokus untuk mendapatkan pasar atau segmen yang mereka inginkan. Produk yang mereka buat lebih banyak menyesuaikan permintaan pelanggan seperti hal yang sedang banyak permintaan maka akan dibuat, namun tetap dengan kekhasan cafe dan restoran mereka. Hal tersebut sesuai dengan pendapat Porter dalam Hitt (2011) dimensi strategi bersaing diantaranya berfokus pada tiga yaitu kepemimpinan biaya rendah disini perusahaan bekerja keras untuk mencapai 
biaya produksi dan distribusi terendah sehingga dapat menetapkan harga lebih rendah ketimbang pesaingnya dan berhasil merebut pangsa pasar lebih besar. Diferensiasi disini perusahaan memusatkan perhatian untuk menciptakan dini produk dan program pemasaran yang berbeda sehingga akhirnya muncul sebagai pemimpin kelas dalam industri. Fokus disini perusahaan memusatkan perhatian pada usaha melayani beberapa segmen pasar dengan baik dan bukannya mengambil seluruh pasar. Selain itu Cara perusahaan untuk mendapatkan keunggulan kompetitif yang berkelanjutan merupakan inti dari strategi bersaing. Pilihan strategi bersaing didasarkan pada keunggulan kompetitif yang dapat dikembangkan oleh organisasi. Bagaimana cara organisasi akan bersaing dalam suatu industri adalah pilihan strategi bersaing. Menurut Porter dalam Wheelen and Hunger (2012), strategi bersaing dapat dilakukan dengan kepemimpinan biaya, diferensiasi, dan focus atau biasa disebut dengan strategi bersaing generik.

Tabel 5 Statistik Deskriptif Variabel pada Strategi Bersaing

\begin{tabular}{|l|c|c|c|c|}
\hline & Min & Max & Mean & $\begin{array}{c}\text { Std. } \\
\text { Dev }\end{array}$ \\
\hline $\begin{array}{l}\text { Kepemimpinan } \\
\text { Biaya }\end{array}$ & 2 & 5 & 3,33 &, 579 \\
\hline $\begin{array}{l}\text { Diferensiasi } \\
\text { Produk }\end{array}$ & 2 & 5 & 3,10 &, 741 \\
\hline Fokus & 2 & 5 & 3,72 &, 547 \\
\hline Strategi bersaing & 2 & 4 & 3,39 &, 471 \\
\hline Valid N (listwise) & & & & \\
\hline
\end{tabular}

Berdasarkan Tabel 5 dimensi pertama adalah dimensi kepemimpinan biaya, yang termasuk kategori cukup baik/tinggi. Hal ini mengindikasikan bahwa UKM cafe dan restoran di Kota Bandung Kecamatan Bandung Wetan menggunakan strategi bersaing kepemimpinan biaya yang tidak terlalu banyak dibandingkan fokus. Hasil observasi yang dilakukan, sebagian besar memilih harga dengan range yang tidak jauh berbeda dengan para pesaingnya. Jika dilihat dari hal tersebut, berdasarkan observasi perusahaan banyak yang mengambil harga berdasarkan harga produksi yang di sesuaikan dengan cafe dan restoran di Bandung lainnya, sehingga tidak terlalu tinggi namun tidak juga murah. menurut Miles dan Snow dalam Suhartati and Rosietta (2012) Analyzer; kelompok perusahaan yang menggunakan kombinasi prospector dengan defender. Artinya perusahaan tidak berani ambil resiko dalam berinovasi, tetapi tetap berupaya menciptakan keunggulan dalam pelayanannya kepada pasar.

Sedangkan dimensi kedua adalah dimensi diferensiasi bersaing, dimensi ini memiliki nilai rata-rata (mean) paling terendah di dalam variabel strategi bersaing, walaupun dimensi ini memiliki rata-rata yang paling rendah, tetapi masuk pada kategori cukup baik/tinggi. Hal ini mengindikasikan bahwa UKM cafe dan restoran di Kota Bandung Kecamatan Bandung Wetan telah memiliki strategi untuk mempunyai ciri khas pada produk yang mereka miliki, namun masih atau banyak yang mudah ditiru oleh pesaing. Berdasarakan hasil observasi lapangan UKM cafe dan restoran Kota Bandung Kecamatan Bandung Wetan sudah melakukan inovasi baik rasa, tampilan ataupun nama yang menjadi ciri khas dari perusahaan mereka. Ada yang menambahkan bumbu yang menjadi ciri khas mereka; topping atau tambahan yang menarik pada menu; tampilan ruangan yang cocok untuk objek foto di sosial media seperti instagram; melakukan pemasaran yang menarik sebagai daya tarik perusahaan. Hal ini sudah sesuai dengan teori Porter dalam Hitt (2015) pada strategi bersaing generic, diferensiasi adalah perusahaan memusatkan perhatian untuk menciptakan dini produk dan program pemasaran yang berbeda sehingga akhirnya muncul sebagai pemimpin kelas dalam industri. 
Hal ini dapat membantu untuk memenangkan pasar.

Dimensi yang ketiga dalam variable strategi bersaing adalah fokus. Fokus disini artinya perusahaan memusatkan pada segmen tertentu, untuk menyesuaikan pemasaran apa, serta produk yang sesuai dari pada segmen pasar yang dituju. Dimensi ini menjadi dimensi yang memiliki nilai rata-rata paling tinggi dalam variabel strategi bersaing dengan nilai rata-rata (mean) 4,18. Nilai rata-rata dimensi fokus ini termasuk pada kategori baik/tinggi. Dibandingkan dengan kedua dimensi sebelumnya dimensi fokus adalah dimensi yang paling tinggi, hal tersebut mengartikan bahwa UKM cafe dan restoran di Kota Bandung Kecamatan Bandung Wetan melakukan strategi bersaing yang bertitik berat pada fokus. Hal tersebut sesuai dengan teori Porter dalam Hitt (2015) fokus yang dimaksud adalah perusahaan memusatkan perhatian pada usaha melayani beberapa segmen pasar dengan baik dan bukannya mengambil seluruh pasar.

Berdasarkan hasil observasi lapangan bahwa UKM cafe dan restoran di Kota Bandung Kecamatan Bandung Wetan membuat menu, dan pemasaran berdasarkan segment pasar tertentu yang mereka tuju. Kebanyakan dari cafe dan restoran memfokuskan segmen anak muda yang menyukai gaya hidup makan di luar rumah, dan menyukai tempat yang bagus untuk menjadi objek foto di sosial media mereka, sehingga para UKM cafe dan restoran banyak melakukan promosi melalui sosial media, seperti instagram, dengan konsep ruangan yang modern dan unik menjadi tempat yang banyak dicari oleh konsumen segmen anak muda; menu makanan yang unik seperti ketersediaan level kepedasan yang berbeda, topping atau tambahan yang unik menyesuaikan dengan minat konsumen.

\section{Analisis Hubungan Kepemimpinan Stratejik dan Strategi Bersaing}

Dalam penelitian, kepemimpinan stratejik diprediksi dapat mempengaruhi strategi bersaing UKM cafe dan restoran di Kota Bandung Kecamatan Bandung Wetan (positif). Dari Tabel 6 diperoleh nilai konstanta (a) sebesar 16,043 dengan koefisien regresi (b) sebesar 0,306. Maka persamaan regresi pada penelitian ini adalah:

$\mathrm{Y}=\mathrm{a}+\mathrm{bX}$

$Y=16,043+0,306 X$

Persamaan tersebut artinya tanpa kepemimpinan stratejik maka variabel dependen atau strategi bersaing hanya mencapai nilai sebesar (a) yaitu 16,043. Koefisien regresi (a) bernilai positif jika terjadi penambahan satu satuan pada $X$ maka akan meningkatkan $\mathrm{Y}$ sebesar (b) 0,306, dengan kata lain jika kepemimpinan stratejik ditingkatkan maka variabel daya saing akan meningkat pula begitupu sebaliknya. Jika dibuat secara grafik, maka garis ditarik dari titik konstanta yaitu 16,043. Sedangkan jika melihat kolom standarized coefficients nilai koefisien regresi sebesar 0,401. Maka persamaan regresi pada penelitian ini adalah:

$\mathrm{Y}=\mathrm{bX}+$ residual

$\mathrm{Y}=0,401+$ residual

Tabel 6 Hasil Uji Regresi dan Uji T

\begin{tabular}{|c|l|r|r|r|r|r|}
\hline \multirow{2}{*}{ Model } & \multicolumn{2}{|c|}{ Unstandardized Coefficients } & \multirow{2}{*}{$\begin{array}{c}\text { Standardized } \\
\text { Coefficients }\end{array}$} & \multirow{2}{*}{ T } & \multirow{2}{*}{ Sig. } \\
\cline { 3 - 5 } \multicolumn{2}{|c|}{} & B & Std. Error & Beta & & \\
\hline 1 & (Constant) & 16,043 & 3,511 & & 4,570 &, 000 \\
\cline { 2 - 6 } & Kepemimpinan Stratejik &, 306 &, 067 &, 401 & 4,555 &, 000 \\
\hline
\end{tabular}

a. Dependent Variable: Strategi_Bersaing 
Dari persamaan tersebut, jika tanpa variabel independen yaitu kepemimpinan stratejik maka varabel depeneden atau strategi bersaing mempunyai nilai nol. Koefisien regresi (b) bernilai positif berarti jika terjadi penambahan satu satuan pada $X$ maka aan meningkatkan Y sebesar (b) yaitu 0,401, dengan kata lain kepemimpinan stratejik ditingkatkan maka variabel strategi bersaing akan meningkat pula bergitupun sebaliknya.

Tabel 7 Hasil Koefisien Determinasi

\begin{tabular}{|l|c|r|r|r|}
\hline Model & $\mathrm{R}$ & $\begin{array}{c}\mathrm{R} \\
\text { Square }\end{array}$ & $\begin{array}{c}\text { Adjusted } \\
\text { R Square }\end{array}$ & $\begin{array}{c}\text { Std. Error of } \\
\text { the Estimate }\end{array}$ \\
\hline 1 &, $401^{\mathrm{a}}$ &, 1608 &, 153 & 3,903 \\
\hline
\end{tabular}

Berdasarkan hasil penelitian yang telah dilakukan juga menunjukkan bahwa terdapat hubungan prositif yang kuat antara kepemimpinan stratejik dengan strategi bersaing. Hal ini didasarkan pada nilai $R$ square sebesar 0,401 yang berada pada interval 0,30-0,49 yang termasuk kategori hungan positif moderat. Selain itu beradasarkan hasil regresi linier sederhana menunjukkan $R$ square atau koefisien determinasi sebesar 0,1608 atau 16,08\%. Angka ini mengartikan bahwa kepemimpinan stratejik dapat memberikan kontribusi atau pengaruh sebesar 16,08\% terhadap strategi bersaing yang diambil oleh UKM cafe dan restoran di Kota Bandung Kecamatan Bandung Wetan yang berasal dari pemimpin yang paham visi dan tujuan perusahaan namun masih tidak konsisten; pemimpin yang paham terhadap model artikulasi bisnis perusahaan, sehingga mengetahui penanganan masalah di perusahaan; menyampainkan informasi dan arahan dengan jelas sehingga karyawan mengetahui apa yang harus dilakukan; mau dan mampu mendelegasikan tugas dan demokratis kepada karyawan; serta memiliki kendali diri dalam menyelesaikan masalah sendiri serta peduli pada karyawan, sehingga dapat mencapai tujuan perusahaan memenangkan pasar.
Sementara sisanya yaitu $100 \%$ $16,08,2 \%=83,92 \%$ merupakan kontribusi dari faktor-faktor lain terhadap strategi bersaing selain kepemimpinan stratejik yang tidak diteliti pada penelitian ini. Faktorfaktor lain tersebut seperti lingkungan eksternal maupun internal perusahaan hal ini dikemukakan oleh Wheelen dan Hunger (2012) menyatakan bahwa proses manajemen strategi meliputi empat elemen dasar yaitu identifikasi faktor internal dan eksternal perusahaan, formulasi strategi, implementasi strategi dan evaluasi strategi. Sebelum melakukan formulasi strategi perusahaan harus melakukan riset terhadap lingkungan eksternal maupun internal perusahaan. Hal ini sesuai dengan penelitian Hertawan (2015) yang menyatakan bahwa lingkungan bisnis dan kepemimpinan stratejik memberikan pengaruh yang lebih besar terhadap kinerja bisnis melalui strategi bersaing dibandingkan dengan pengaruh langsung lingkungan bisnis dan kepemimpian stratejik terhadap kinerja bisnis. Lingkungan bisnis mempengaruhi strategi bisnis sebesar 0,805 atau 8,05\%, namun pada peneltian ini kepemimpinan stratejik mempengaruhi strateg bisnis sebesar 0,171 atau $1,71 \%$. Hal ini berbeda dengan penelitian penulis yang menyatakan bahwa kepemimpinan stratejik berpengaruh lebih besar penelitain sebelumnya. Hal ini mengindikasikan bahwa kepemimpinan stratejik memiliki peran cukup besar dalam melakukan formulasi strategi bersaing.

Dengan demikian UKM cafe dan restoran di Kecamatan Bandung Wetan Kota Bandung dapat menerapkan kepemimpinan stratejik pada kegiatan bisnis mereka. Hal tersebut dikarenakan sesuai dengan pemaparan di atas bahwa kepemimpinan stratejik berpengaruh positif dan signifikan terhadap strategi.

\section{KESIMPULAN DAN SARAN Kesimpulan}

1. Kepemimpinan stratejik yang dilakukan UKM cafe dan restoran di Kecamatan Bandung Wetan Kota Bandung berada 
pada kategori cukup baik. Hal ini dilihat dari lima dimensi dari variable kepemimpinan stratejik yaitu visi, artikulasi model bisnis, menyampaikan infomasi dengan baik, cerdik dalam menangani kekuasaan, dan kecerdasan emosional yang berada pada tingkat yang cukup baik.

2. Strategi bersaing yang dilakukan oleh UKM cafe dan restoran di Kecamatan Bandung Wetan Kota Bandung berada pada kategori cukup baik, dilihat dari tiga dimensi strategi bersaing yaitu yang berada pada tingkat cukup baik.

3. Berdasarkan hasil analisis korelasi dan uji hipotesis dapat disimpulkan bahwa penerapan kepemimpinan stratejik berkontribusi positif. Hal ini didasarkan pada analisis korelasi sebesar 0,401 yang termasuk kategori sedang Berdasarkan nilai koefisien determinasi, kontribusi kepemimpinan stratejik terhadap strategi bersaing pada UKM cafe dan restoran di Kecamatan Bandung Wetan Kota Bandung menunjukkan niali sebesar 0,1608 atau $16,08 \%$ artinya kepemimpinan stratejik berkontribusi sebesar $16,08 \%$ terhadap strategi bersaing yang berasal dari pemimpin yang paham dan kosistensi visi dan tujuan perusahaan; pemimpin yang paham terhadap model artikulasi bisnis perusahaan, sehingga mengetahui penanganan masalah di perusahaan dengan mengikutsertakan karyawan; menyampaikan informasi dan arahan dengan jelas; bijak dalam mendelegasikan tugas dan demokratis kepada karyawan; serta memiliki kendali diri dalam menyelesaikan masalah sendiri serta peduli pada karyawan, sehingga dapat mencapai tujuan perusahaan memenangkan pasar. Sementara sisanya sebesar $83,9 \%$ merupakan faktor yang tidak diteliti.

\section{Saran}

1. UKM cafe dan restoran di Kecamatan Bandung Wetan Kota Bandung disarankan untuk terus menerapkan kepemimpinan stratejik bahkan meningkatkan penerapannya. Hal ini didasarkan pada hasil penelitian yang menunjukkan bahwa kepemimpinan stratejik berpengaruh positif dan terhadap strategi bersaing pada UKM cafe dan restoran. Demi meningkatkan penerapan kepemipinan stratejik yang sudah cukup baik ini, pemimpin harus bersikap terbuka dan berpikir jauh ke depan sehingga pemimpin bisa melihat model bisnis apa yang akan datang, trend apa yang akan terjadi, terus menyampaikan visi serta tujuan perusahaan kepada karyawan, dan konsisten sehingga visi tersebut menjadi budaya di organisasi; selalu berusaha untuk menyelesaikan masalah di perusahaan dengan menerima banyak perubahan seiring dengan perkembangan zaman; menyampaikan informasi dan arahan dengan jelas dan lengkap, dan menyampaikan apa yang terjadi di perusahaan; bijak dan mendelegasikan tugas dan demokratis; serta dapat mengendalikan diri dalam menyelesaikan masalah dan paham terhadap masalah karyawan.

2. UKM cafe dan restoran di Kecamatan Bandung Wetan Kota Bandung harus terus meningkatkan strategi bersaing yang sudah masuk kategori cukup baik. Untuk menjaga strategi bersaing yang baik tersebut, UKM harus mampu menentukan strategi mana yang sesuai untuk perusahaannya sendiri, baik itu dengan harga yang murah, produk atau pemasaran yang tidak pasaran atau unik, atau fokus terhadap segmen pasar yang ingin dituju. Sehingga dengan strategi bersaing yang baik, UKM tersebut dapat memenangkan pasar di industri cafe dan restoran.

3. Bagi peneliti selanjutnya diharapkan lebih memperluas penelitian ini, baik dari segi dimensi yang digunakan maupun objek penelitian. 
DAFTAR PUSTAKA

Alfred, D. \& Chandler, Jr. (1962). Strategy and Structure: Chapters in The History of The industrial Enterprise. Cambridge Mass: MIT Press

Barokah, S. N. (2012). Studi Tentang Faktor-Faktor Yang Mempengaruhi Kualitas Strategi Bersaing Untuk Meningkatkan Kinerja Perusahaan Pada Kukm Pengrajin. Jurnal Bisnis dan Manajemen, 20(1).

Cohen, L. (2017). Research Methods in Education. (Sicth edition). New York: Routledge

Dess, G. G., Lumpkin, G. T., \& Eisner, A. B. (2008). Strategic Management : Text and Cases. New York: McGraw Hill.

Dudin, A. Y., \& Al-rabah, R. A. A. (2015). Strategic Leadership And Their Effect On Managing Organizational Change" : Case Study Zarqa University. European Journal of Business and Social Sciences, 3(12), 81-89.

Hill \& Jones. (2013). Theory of Strategy Management (Competitive \& Globalization). South Western: Cengage Learning.

Hitt, A. I. (2011). Conceps Strategic Management - Competitiveness and Globalization. Canada: SouthWestern Cencage Learning,.

Mahmud. (2011). Metode Penelitian Pendidikan. Bandung: Pustaka Setia

Mintzberg, H., Quinn, J. B. \& Voyer, J. (1995). The Strategy Process. PrenticeHall, Inc,

Porter, M. E. (2004). Competitive Strategy Techniques for Analizing Industries and Competitors. New York: Free Press

Terry, R. G. (2006). Prinsip-Prinsip Manajemen. Jakarta: Bumi Aksara

Rothaerment, F. T. (2015). Strategic Management. New York: McGraw-Hill

Sachin, D. S., \& Bansidhar, D. S. (2013). Strategic Leadership: A Need of Today's a Competitive Era. International Journal on Leadership, 1(1).
Sugiyono. (2012). Metode Penelitian Kuantitatif, Kualitatif dan $R$ \& $D$. Bandung: Alfabeta.

Sugiyono. (2013). Statistika untuk Penelitian. BAndung: Alfabeta.

Suhartati, T., \& Rosietta, H. (2012). Pengaruh Strategi Bersaing Terhadap Hubungan Antara Supply Chain Management dan Kinerja (Studi Pada Perusahaan Manufaktur yang Teradafatar di BEI). Jurnal Bisnis dan Manajemen PNJ, 1(30).

Thoyib, A. (2012). Hubungan Kepemimpinan, Budaya, Strategi, dan Kinerja: .

Umar, H. (2011). Metode Riset Perilaku Organisasi. Jakarta: Gramedia.

Wheelen \& Hunger. (2012). Strategic Management and Business Policy (Vol. 12 Edition): Pearson.

Yulk, G. (2010). Kepemimpinan dalam Organisasi (Vol. Edisi Kelima). Jakarta: PT. Indeks. 